Northwestern University School of Law Northwestern University School of Law Scholarly Commons

Faculty Working Papers

2009

\title{
International Responses to Territorial Conquest
}

Eugene Kontorovich

Northwestern University School of Law, e-kontorovich@law.northwestern.edu

\section{Repository Citation}

Kontorovich, Eugene, "International Responses to Territorial Conquest" (2009). Faculty Working Papers. Paper 180.

http://scholarlycommons.law.northwestern.edu/facultyworkingpapers/180

This Article is brought to you for free and open access by Northwestern University School of Law Scholarly Commons. It has been accepted for inclusion in Faculty Working Papers by an authorized administrator of Northwestern University School of Law Scholarly Commons. 


\section{International Responses to Territorial Conquest}

\section{Eugene Kontorovich ${ }^{*}$}

The prohibition on territorial conquest is a cornerstone of the international legal order. The United Nations Charter bans the use or threat of force as a tool of international relations, even when used to rectify prior injustices. The sole exception is self-defense. Thus territory taken by force has the status of ill-gotten gains, and cannot be kept by the victor.

An important corollary is that third-party states cannot recognize the sovereignty of the conqueror or otherwise treat the acquisition as illegal. ${ }^{1}$ Given the stillbirth of the U.N. collective security system, nonrecognition is one of the few realistic ways the international community has sanctioning deterring conquerors. This much is taken as axiomatic in international law. Indeed, the anti-conquest norm and its nonrecognition corollary are so important that in the view of most international lawyers, even conquest through lawful self-defense against an aggressor is forbidden.

Despite the Charter, nations sometimes acquire or try to acquire territory through force. The standard response of international lawyers to violations of international norms is to stress that such behavior does not prove the absence or weakness of the norm. What's important for assessing a norm's vitality is the international legal community's

\footnotetext{
${ }^{*}$ Associate Professor, Northwestern University School of Law; Senior Research Fellow, International Law Forum at the Jerusalem Center for Public Affairs.

${ }^{1}$ Declaration of Principles of International Law Concerning Friendly Relations and Co-operation Among States in Accordance With the Charter of the United Nations, G.A. Res. 2625 (1970) ("No territorial acquisition resulting from the threat or use of force shall be recognized as legal.”); Third Report on State Responsibility: Report by Special Rapporteur James Crawford, at 23, para. 410 (2000) ("States may not recognize as lawful, for example, a unilateral acquisition of territory procured by the use of force, even if the use of force was arguably lawful.”).
} 
response to violations. If nations respond to a violation of a norm by condemning it as such, it suggests the norm is not a dead letter.

I will discuss the very preliminary and tentative findings of a project that seeks to asses the nature of third-party reactions to territorial conquest. It examines the international reaction every consummated conquest since the entry into force of the UN Charter. It does not examine the incidence of aggression or even of conquest. The question is, given a conquest, what is the expected international reaction?

While territorial conquest has been relatively infrequent in the post-World War II period, most conquests have not been condemned by the international community. Indeed, acceptance is as common as condemnation. While little can be said about the deterrent effect of the anti-conquest norm, the punitive effect appears insignificant. The small likelihood of international opposition to conquest suggests that the relatively low incidence of conquest should be attributed to causes other than the non-recognition norm.

Several scholars have examined territorial aggression in the postwar period. The political science literature empirically examines the correlates and causes of aggression and successful conquest. ${ }^{2}$ This literature is mostly interested in the primary behavior, not the legal sanction it receives. The one major project to look at international legal reactions to conquest takes an in-depth case-study approach, examining five episodes. ${ }^{3}$ Given the relatively small number of conquests in the post-war period, systematically looking at the legal reaction to all of them seems plausible and worthwhile. This project

\footnotetext{
${ }^{2}$ Mark Zacher, The Territorial Integrity Norm: International Boundaries and the Use of Force, 55 International Organization 215 (2001); Jaroslav Tir, et al., Territorial Changes, 1816-1996: Procedures and Data, 16 CONFlict MANAgEMENT AND PEACE SCIENCE 89 (1998).

${ }^{3}$ See Sharon Korman, The Right of Conquest: The ACquisition of Territory by Force in INTERNATIONAL LAW AND PRACTICE 249-302 1996).
} 
looks at questions not answered in the political science literature, and at a fuller set of conquests than Korman.

Approaching this question involves several methodological problems. The biggest is determining what counts as a "conquest” for purposes of this study. The existing political science datasets focus on aggression, not conquest per se. The difference between aggression and conquest is success. Separating conquest from aggression requires some duration criterion. Not having such a requirement would be vastly overinclusive: any territorial encroachment, no matter how brief, in any minor cross border skirmish could count as conquest. On the other hand, any duration requirement would weeding out many attempted conquests. By looking for consummated conquests, the definition would miss abortive or rapidly defeated aggressions. For example, if one counts conquests - as this project tentatively does - only those lasting a year or more, one would leave out such a major episodes of the Iraqi invasion of Kuwait and the Argentinean seizure of the Falklands.

The central problem is that the difference between conquest and aggression are occupation is largely one of intent, and perhaps success. This project assumes such intent only when clearly manifested in conduct. There are several justifications for using this stricter definition of conquest. First, defeated attempts at conquest are certainly far fewer than the hundreds of thousands of shorter territorial encroachments that could be thought of as "transient conquests." Second, one may expect of international reaction to consummated conquests would be different from attempted ones. In the latter case, condemnation may be slow in coming as nation's hope the victim state will deal with the situation itself. Conquest implies a certain permanence. Conquest is regarded as worse 
than the aggression, so one would expect on this ground criticism to be are more readily evident when the permanent intention becomes clear. ${ }^{4}$

Whatever the limitations of this definition, it allows focusing on a particular question - the international response to conquest and the vitality of the nonrecognition norm. While attempted or pending conquest may be criticized, such denunciation may turn out to bee short-lived in the face of a fait accompli. It is precisely for durable conquests that the obligation on third-party states to treat conquests as illegal exists. The focus of this inquiry is what happens when nations do conquer. It is an examination of a penal norm. If one were to want to see how law treated murderers, it would be proper to exclude attempted murders from the study.

The other major methodological question concerns classifying the international response. While international reaction is a continuum, one can conveniently think of three broad reactions to conquest: condemnation, approval, and silence or acquiescence. The lack of any clear response by the majority of nations would suggest acquiescence, even if particular nations took strong positions. Condemnation could be most clearly expressed by a Security Council resolution, which appears to be what the Charter ideally contemplates. A critical General Assembly resolution also shows broad condemnation. In the absence of U.N. resolution clearly condemning war approving a conquest, one must look to the actions of individual states. This route poses the most difficulties.

Depending on certain coding decisions, there have been somewhere between 12 and 18 forcible conquests by existing states after the adoption of the U.N Charter. ${ }^{5}$

\footnotetext{
${ }^{4}$ Perhaps international condemnation could effect the success of an attempted conquest -- though short of intervention, as in Korea and Iraq, the mechanism of such an effect is obscure. In such a case, a study of consummated conquests would be biased towards those territory-seeking aggressions of which the international community is more tolerant.
} 
International condemnation is found in only a few cases. ${ }^{6}$ Other conquests have won overwhelming international acceptance; these interestingly include both conquests of entire nations. ${ }^{7}$ The majority of conquests receive no clear international response. ${ }^{8}$

Taking the conquests at their smallest number, international condemnation is found in less than one-quarter; and international approval is at least at common as rejection, though acquiescence accounts for at least half the cases. Thus a country that can successfully conquer and hold territory for a year has little likelihood of facing international condemnation. Nor does there appear to be, at first glance, a connection between the magnitude of the conquest and the reaction, except that very small acquisitions will likely be met with indifference.

Notably, there has not been any successful conquests since 1975. On the other hand, it seems the period since then has seen numerous invasions that created de fact control of nominally independent states dependent on the conqueror. ${ }^{9}$ Such pseudoconquests do not fall within the scope of this project, and thus one can only conjecture at whether they have increased as a result of the non-acquisition norm.

\footnotetext{
${ }^{5}$ One can debate, for example, whether to included situations where the force was largely applied before the adoption of the charter, but the conquest was in some sense consummated afterwards - such as the redistribution of territory from Axis powers to other states in 1947, or South Africa's presence in Southwest Africa (Namibia).

${ }^{6}$ The clearest are Morocco's taking of Spanish territory in Western Sahara and Indonesia is taking Portuguese East Timor, both in 1975. Both were condemned by Security Council resolutions. Israel's taking of Syrian, Egyptian, and Jordanian-occupied territory in 1967 received a mix of condemnation and approval in S.C. 242, but was clearly denounced in a subsequent G.A. resolution.

${ }^{7}$ China /Tibet in 1950 and North Vietnam/South Vietnam in 1975. Other conquests that are almost universally treated as part of the sovereign territory of the conqueror are India's takeover of Portuguese territories in 1961 and Indonesia's conquest of Dutch New Guinea in 1963. Both Indian and Pakistani acquisitions in the Kashmir are widely treated as de facto parts of those countries, but this might also be a case of acquiescence.

${ }^{8}$ These conquests include smaller territorial changes, such as Egypt/Palestine (1949); Jordan/Palestine (1949); China/India (1962); Iran/United Arab Emirates (1971); China/South Vietnam (1974); Libya/Chad (1973-87).

${ }^{9}$ Notable examples included Vietnam/Laos; Vietnam/Cambodia Syria/Lebanon; U.S.S.R./Afghanistan; and much more controversially, NATO/Serbia (in Kosovo).
} 
